\title{
The system of functioning of out-of-school education in modern conditions of development
}

\section{O sistema de funcionamento da educação fora da escola em condições modernas de desenvolvimento}

\section{El sistema de funcionamiento de la educación extraescolar en condiciones modernas de desarrollo}

\author{
Tetiana Fursykova1 $^{\text {iD }}$, Oleksandr Akimkin² iD, Liliia Hodii ${ }^{3}$ iD

\footnotetext{
${ }^{1}$ Department of Art Education, Volodymyr Vynnychenko Central Ukrainian State Pedagogical University, Kropyvnytskyi, Ukraine.

${ }^{2}$ Commission on Commodity Research and Marketing, M.P. Saya Kirovohrad Cooperative Professional College of Economics and Law, Kropyvnytskyi, Ukraine.

${ }^{3}$ Personnel Department, Lviv State University of Life Safety, Lviv, Ukraine.
} \\ Corresponding author: \\ Tetiana Fursykova \\ Email: Sydorchenko_Teti@ukr.net
}

How to cite: Fursykova, T., Akimkin, O., \& Hodii, L. (2022). The system of functioning of out-of-school education in modern conditions of development. Revista Tempos e Espaços em Educação, 15(34), e16860.

http://dx.doi.org/10.20952/revtee.v15i34.16860

\begin{abstract}
The main purpose of the study is to define and characterize the system of out-of-school education in modern conditions of development. The urgency of the topic is due to the fact that out-of-school education began to be considered as one that reveals the immediate prospects for personal development in various social and educational institutions, where out-of-school institutions were to become centers of motivational development, self-realization and professional selfdetermination. The question arose about the place of out-of-school education in the single educational space, determining its relationship with other levels of education, the prospects for the functioning of out-of-school institutions in the market of educational services. Economic and political instability of socio-cultural systems, increasing negative effects of natural factors, the residual principle of financing out-of-school institutions have led to a decrease in their efficiency and decline of educational facilities, which significantly hindered the full use of out-of-school education. According to the results of the analysis, a study of the main aspects of the functioning of out-of-school education in modern conditions of development was conducted.
\end{abstract}

Keywords: Education. Educational institutions. Modern education. Out-of-school education. 


\section{RESUMO}

O objetivo principal do estudo é definir e caracterizar o sistema de educação extra-escolar em condições modernas de desenvolvimento. A urgência do tema se deve ao fato de a educação fora da escola passar a ser considerada como aquela que revela as perspectivas imediatas de desenvolvimento pessoal em diversas instituições sociais e educacionais, onde as instituições fora da escola viriam a se tornar centros de. desenvolvimento motivacional, autorrealização e autodeterminação profissional. Colocou-se a questão sobre o lugar da educação fora da escola no espaço único educacional, determinando sua relação com os demais níveis de ensino, as perspectivas de funcionamento das instituições fora da escola no mercado de serviços educacionais. A instabilidade econômica e política dos sistemas socioculturais, aumentando os efeitos negativos dos fatores naturais, o princípio residual do financiamento das instituições fora da escola levou a uma diminuição na sua eficiência e ao declínio das instalações educacionais, o que prejudicou significativamente o uso pleno das instituições. educação fora da escola. De acordo com os resultados da análise, foi realizado um estudo sobre os principais aspectos do funcionamento da educação extra-escolar nas condições modernas de desenvolvimento.

Palavras-chave: Educação fora da escola. Educação moderna. Educação. Instituições educacionais.

\section{RESUMEN}

El objetivo principal del estudio es definir y caracterizar el sistema de educación extraescolar en las condiciones modernas de desarrollo. La urgencia del tema se debe a que se empezó a considerar la educación extraescolar como aquella que revela las perspectivas inmediatas de desarrollo personal en diversas instituciones sociales y educativas, donde las instituciones extraescolares se convertirían en centros de educación. desarrollo motivacional, autorrealización y autodeterminación profesional. Surgió la pregunta sobre el lugar de la educación extraescolar en el espacio educativo único, determinando su relación con otros niveles educativos, las perspectivas de funcionamiento de las instituciones extraescolares en el mercado de servicios educativos. La inestabilidad económica y política de los sistemas socioculturales, el aumento de los efectos negativos de los factores naturales, el principio residual de la financiación de las instituciones extraescolares han provocado una disminución de la eficiencia y el deterioro de las instalaciones educativas, lo que ha obstaculizado significativamente el pleno uso de nuestros -Educación extraescolar. De acuerdo con los resultados del análisis, se realizó un estudio de los principales aspectos del funcionamiento de la educación extraescolar en las condiciones modernas de desarrollo.

Palabras clave: Educación extraescolar. Educación moderna. Educación. Instituciones educativas.

\section{INTRODUCTION}

The decisive role in the organization of out-of-school education was assigned to out-ofschool institutions - multifunctional creative centers for pupils, which had signs of a complex multilevel pedagogical system, where the organization of the educational process was directed not at the maximum load of the child with educational material, but at the development of his abilities, where the pedagogical process was oriented as follows: to evoke positive emotions in the pet and contribute to its full development. They gave knowledge, formed students' skills and abilities in accordance with their interests, provided the individual's needs for creative self-realization, intellectual, spiritual and physical development, prepared for professional and social activities, created conditions for organizing meaningful leisure. Out-of-school institutions become instructive and methodological centers of educational and upbringing work with children during and an experimental laboratory of advanced pedagogical experience, coordinators of this work. Out-ofschool institutions helped the school in organizing the free time of students, created a network of their branches in districts, cities and villages, using the premises of housing and communal departments and village clubs for this. 
The development of the institution of out-of-school education in the context of COVID-19 presupposes its renewal. In turn, such a renewal involves making changes in the organizational culture, therefore, organizational development occurs through the improvement of communications between different parts of the institution of out-of-school education through the spiritual and professional development of its teaching staff. The development strategy of the institution of out-of-school education in the context of COVID-19 is determined by: mission, competitiveness of the educational market and labor market, the needs of customers for software services; a scientifically based and structured goal system; rationality, targeting the distribution of human, energy, information, technological, financial, technical resources; "distribution of responsibility and determination of the timing of strategic actions"; "The level of strategic thinking formation"; "The introduction or development of effective methodologies for the formation of strategies"; "The ability to carry out organizational development"; "the ability to identify the organization with the external environment", with the luminous space in which the interaction of educational environments and forms of existence of the educational community as a sociocultural and sociopsychological phenomenon occurs.

The development strategy of the institution of out-of-school education in the context of COVID-19 depends on the ability of the subjects of management to choose it and apply strategic management. The management strategy in the context of COVID-19 should be considered in two social aspects: management taking into account the interaction with the environment, which ensures the life of the institution through adaptation in the environment and the corresponding development of development goals, and personnel management, which provides for the achievement of joint team activities.

The process of education management presupposes the decentralization of the education system of the country as a whole, a prerequisite for which is the provision of autonomy to local selfgovernment in determining the directions of development of the education system of the territorial community. This enables local authorities to realize their individuality, independently determining the mechanisms and strategies for the development of the educational system and its components. On the other hand, the responsibility of local authorities for the success of educational activities also increases significantly. This is especially true for the most dynamic spheres of education, among which out-of-school education occupies one of the first places. Indeed, in the conditions of the market and decentralization, it increasingly appears at the same time as a producer of social benefits, focuses on public needs, and as a market entity, focuses on the market of educational services in the context of COVID-19. All this raises the problem of the municipal management of out-of-school education in a new way.

In our opinion, it is at the level of local self-government that it is necessary to create appropriate conditions for the development of the industry as an effective intellectually rich environment in the educational space. Such a result is possible in the case of combining the efforts of public authorities and local self-government, as well as educational institutions, institutions and organizations. Today, in the context of COVID-19, regionalization and municipalization of the educational system should be on the agenda. Its ultimate goal is to meet the growing needs for quality education at all levels. It is out-of-school education that is capable of complementing, deepening, expanding the boundaries of preschool, primary, incomplete secondary, pre-profile, profile, general secondary, vocational and technical educational levels. At the same time, it turns out not only to be an effective means in the process of integrating the basic competencies that the child masters during the entire learning process, but also lays the foundations for self-development and professional self-determination in the future. 


\section{METHODOLOGY}

The main purpose of the study is to define and characterize the system of out-of-school education in modern conditions of development. We used a number of methods to conduct our research, which together form our methodology. These methods, which form the methodology of the study, include: systems analysis and synthesis, induction and deduction, comparison, classification, generalization and systematization, idealization and abstraction.

\section{RESULTS AND DISCUSSION}

In the new socio-economic conditions, under the influence of COVID-19, a new personalityoriented model of the educational process of an out-of-school institution was formed, which was aimed at the formation of an educated person, actively, constructively and creatively acts in a democratic society built on the basis of market relations and should ensure and preserve for each child the opportunity to develop himself according to his own interests, abilities and talents.

The main forms of scientific and methodological support of out-of-school education are educational and scientific publications, including: curricula, textbooks, teaching aids, guidelines, etc. Different types of out-of-school institutions created their own programs, distinguished by the originality of the teacher's approach. Methodological developments of teachers of out-of-school children were published in periodicals, which facilitated the exchange of their experience.

Key elements in the field of organizational support of out-of-school education are presented in table 1.

Table 1. Key elements in the field of organizational support of out-of-school education.

\begin{tabular}{|c|c|}
\hline № & Key elements \\
\hline 1 & Formation of a multilevel system of out-of-school education \\
\hline 2 & $\begin{array}{l}\text { Classification of circles, groups and other creative associations of an out-of-school } \\
\text { institution according to three levels (primary, basic, higher) }\end{array}$ \\
\hline 3 & $\begin{array}{l}\text { expansion of the network of out-of-school establishments, the creation of new types of } \\
\text { establishments, their profiling }\end{array}$ \\
\hline 4 & diversification of funding sources for out-of-school education \\
\hline
\end{tabular}

The main directions of development of the institution of out-of-school education in the context of COVID-19, as a strategically oriented organization, in the face of constant changes in education, society, economy, politics, ecology are:

1) ensuring equal access to quality out-of-school education;

2) development of the student and teaching staff;

3) introduction of the latest pedagogical technologies;

4) development of organizational culture, creation of an atmosphere of psychological comfort and safety;

5) ensuring professional and creative development and growth of the educational and qualification level of teaching staff;

6) improvement of the material base and information and communication support.

A modern institution of out-of-school education in the context of COVID-19 is a kind of intellectually creatively developed community of subjects of the educational process as an integrity, which is characterized by purposefulness, a multi-age composition of applicants for out-of-school education, formal and informal structures and relationships, autonomy of existence, cyclicity. opinions, views, beliefs and actions in life creation, freedom of choice of forms of out-of-school education and training, types of activities, the ability to gain socially significant experience, play new social roles and not depend on stereotypes of the opinions of others. 
It is important to note that the unusual organization and conduct of classes at advanced training courses for leaders of out-of-school educational institutions is due to the peculiarities of adult education, therefore one of the methodological approaches in their organization is andragogical, favorable to the development and enrichment of the integral personality of a person, manifestation of his originality, its actualization. hidden abilities and opportunities. The educational process at the advanced training courses for the leaders of the circles of out-of-school educational institutions is based on the main provisions of andragogy, the main characteristics of which are the problematic nature of teaching; situationality; dialogicity (Lacerda, Marques, 2021; Santos, Barreto, Soares, 2020; Parente, 2020; Palshkova, Balakirieva, Skoromna, Shpaliarenko, 2021; Castañeda, Dabbagh, Torres-Kompen, 2017).

The analysis of the specific characteristics of out-of-school education and the properties of adult learning allowed us to designate the features of professional development for teachers working in out-of-school educational institutions, namely:

1. Organizational - provide for the scheduling of advanced training courses in accordance with the start and end dates of the school year; the formation of groups in accordance with the directions of out-of-school education, the development of a schedule, programs for teaching practice, and the like.

2. Content - the definition of the content of education in accordance with modern requirements for advanced training, to the content of pedagogical and, in particular, out-of-school education.

3. Procedural - the use of personality-oriented technologies, interactive forms and methods of conducting classes, the introduction of differential and individual approaches.

4. Personal - taking into account the needs of out-of-school teachers, creating a psychological climate in the group.

5. Creativity - the focus of the educational process on the search for non-standard solutions.

Socio-political, economic, scientific, technical, integration and environmental realities determine not only the consideration of the existing regulatory and methodological framework for the interaction of institutions of general secondary and out-of-school education in the aesthetic education of adolescents, but also the analysis and interpretation of existing documents that will make it possible to more effectively carry out this process. interactions. The relevance of the research topic is due to the approval of a new paradigm of education based on the principles of humanism, culture-like, human-centrism, and aesthetic development of personality. Revealing the essence of the normative and methodological foundations of the interaction of institutions of general secondary and out-of-school education in the aesthetic education of adolescents, we will characterize the conceptual level (mega-level of research) of the interaction of institutions of general secondary and out-of-school education in the aesthetic education of adolescents, which is highlighted in the developed multi-vector model and includes general components: subjective and objective signs of society, socio-political, economic and other realities that objectively affect the interaction of institutions of general secondary and out-of-school education in the aesthetic education of adolescents; social situation, allows for the organization, planning (content component), control of educational activities in institutions of general secondary and out-of-school education; the demographic situation in the country, which leads to a revision of the normative and methodological foundations of the interaction of institutions of general secondary and out-ofschool education in the aesthetic education of adolescents, its content; principles, laws, regulations, concepts relating to the organization of educational activities, which are guided and based on the heads of educational institutions during the organization, planning, execution and control of educational and educational activities (Pechenkina, 2017; ZlateaCucui, 2016; Pardeshia, 2014; Carmignolli, Muzzeti, Oliveira, 2020). 
The theoretical and methodological block of the content of out-of-school education is based on the general social pedagogical principles of teaching and upbringing and the principles of out-ofschool education, scientific concepts for the formation of the creative personality of a senior preschooler in an out-of-school educational institution; awareness of the role, objectives and key goals of out-of-school education. The cognitive content of the mentioned component is knowledge about the specifics of personality psychology of preschool age; pedagogical activity of an out-ofschool teacher; understanding of the creative nature of professional activities in an out-of-school educational institution; the concept of pedagogical creativity, its types, levels and criteria, the main psychological and pedagogical conditions that contribute to the process of creativity; the concept of creativity and creativity, giftedness, talent, the ratio of creativity to intellectual, and the like. The development of the content of the activities of an out-of-school educational institution, in our opinion, should be based on such scientific principles, the observance of which ensures the scientific nature, consistency, stages of the educational process, namely:

- the correspondence of the educational content of the sociocultural paradigm; traditions, customs, taking into account the achievements of the cultural and historical heritage of the Ukrainian people; cultural and creative directions in the formation of the basic culture of the individual;

- humanism - recognition of the child as the highest value and the center of the pedagogical system in out-of-school educational institutions, subject to taking into account their psychophysiological characteristics, human-centered principles in communication and relationships with other people on the basis of the implementation of an individual program of education, upbringing and development;

- integrity - the observance of the continuity and logical unity of the directions of educational and upbringing activities, is aimed at the formation of a creatively directed worldview in the consciousness of a growing personality;

- dialogue - adherence to the principles of partner-subject interaction on an equal footing, recognition of rights and freedoms in free expression and upholding their own thoughts;

- life meaning-making activity - the formation of a personality as a creator and designer of his own life path, responsible for his choices and actions;

- the social and personal significance of the child's creative activity - the formation of the personality as a full-fledged and active member of society, which works for its good;

- psychological comfort - ensuring the development of the creative abilities of the personality of the older preschooler through play activities, which are nature-appropriate to the personal needs of a child of this age and is accompanied by a feeling of psychoemotional pleasure.

In addition, the educational process in the out-of-school educational institution is based on the principles that are characteristic of the out-of-school education system - variability and diversity - provides an opportunity for each child and his parents to choose the content, form of organization of education, methods of their implementation in accordance with their own abilities and interests. and educational programs, deepening their practical orientation, differentiation and individualization of both educational and practical work, contributes to the effective development of the intellect and the spiritual development of the child; - integrativeness - a combination of thematic blocks from different subjects (this principle allows a deeper and more versatile penetration into the sides of creativity, contributes to the expansion of the worldview in the process of forming a creatively directed personality, actualization of various types of creative abilities). voluntariness and accessibility - provides for the right of a person to choose directions, content, forms, methods, means and ways to satisfy their own interests and educational needs, to obtain additional knowledge, to develop skills and abilities, to contribute to the creative self-realization of the personality of an older preschooler, as well as accessibility and equality in mastering out-ofschool education for all categories of the population (including those from "risk groups" and children 
with special needs); - the expediency of combining forms, methods and means of teaching and upbringing in out-of-school education in accordance with the content and tasks of out-of-school education reveals the essence of the process of effective definition and application of the whole variety of forms, methods and means of teaching and upbringing in the educational process of an out-of-school educational institution. The effectiveness of its implementation depends on the combination of five groups of conditions: educational, moral, psychological, hygienic, aesthetic and material and technical (Zdanevych, Kharkivska, Popovych, Bobyrieva, Kovrei, 2020; GonzálezMartínez, Bote-Lorenzo, Gómez-Sánchez, Cano-Parra, 2015; Galizina, Palanchuk, Afonin, Krivova, Lyapunova, 2020).

Compliance with these conditions provides for:

- analysis of the educational and creative capabilities of students, analysis of the selected content, forms, methods, means, available conditions and appropriate forecasting of the maximum possible results, determination of the required amount of study time for the implementation of individual content elements;

- focus on the development of the emotional and value sphere of the individual - the implementation of this principle should be aimed at creating pedagogical conditions for a systematic and consistent impact on the personality in order to form not only cognitive, but, above all, emotional and moral qualities based on aesthetic, emotional and artistic, intuitive perception of reality;

- focus on the development of the active-practical sphere of the individual - this principle allows you to see the application of the acquired knowledge and acquired skills in practice, including the use of products of creative and creative activity, contributes to the harmonious integration of the child into the socio-cultural environment;

- Reflexive creativity involves focusing on an individual and creative approach to planning a system of classes, the use of interactive innovative technologies in pedagogical activity.

We consider this principle in the inseparable unity of the teacher's professional and pedagogical self-reflection - creating conditions for independent work of both the teacher and the pupil for his self-development, self-knowledge, self-determination, self-education, self-education, self-realization.

The experimental block of the content of out-of-school education is based on a combination of typical and experimental curricula and work programs of an out-of-school educational institution, identifying the possibilities of creative development of the personality of a senior preschooler by analyzing the content of curricula according to the profiles of the creative direction; modeling various types of classes with the same content, determining the optimal methods for studying a given topic and the most productive assimilation of it by pupils; based on the analysis of the content of the lesson, predicting the appearance of the level of a creatively directed personality; development of creative situations, didactic opportunities for both a specific pupil and certain groups of older preschoolers; development of a set of heuristic questions for control and self-control over creative activity; development of forms and methods of management and self-management of the creative activity of both the teacher and the pupils; co-creation with pupils in choosing the form and technology of conducting an interactive lesson (excursion lessons, adventure lessons, exhibition lessons, concert lessons, etc.).

The experimental block is implemented with certain levels of out-of-school education content.

The first level (informational and cognitive). The content of education and upbringing has a propaedeutic and general developmental direction and, if necessary, is developed for children of different age groups who are just starting to study in out-of-school institutions, or have studied in a different profile. When constructing the content of such programs, first of all, one should take into account the individual level of previously formed knowledge and skills of pupils, the profile of the 
circle, the psychophysiological characteristics of the age group. The purpose of assimilating this level of out-of-school education content is the formation of a stable type of cognitive interest, support of natural curiosity, identification of the natural inclinations of an older preschooler in relation to a certain type of creative orientation (musical, technical, natural, scientific, etc.). The main task of the teacher at this level is the implementation of psychological and pedagogical support of the social and psychological adaptation of pupils to the conditions of the educational institution, the creation of a favorable atmosphere and a friendly climate in children's groups, taking into account the game as a leading type of activity at this age, saturation of the emotional and sensory field of communication and interaction (bright interior decoration, musical means, theatrical performances, etc.), predicting possible crisis situations and creating optimal conditions for the development of children's creativity (under the crisis phenomena we see the fading of interest in any kind of activity).

The second level (activity-transformative). The content of out-of-school education and upbringing is aimed at the formation of practical skills and skills of creative activity directly in the educational process of an out-of-school educational institution. The implementation of the content is introduced through various forms and methods (lesson-demonstration, lesson-lecture, circle club work, individual lessons, conferences, presentations in nature and in other institutions stipulated by the Charter of the out-of-school educational institution). The purpose of mastering the specified level of educational content is to familiarize oneself with various types of creative activity and the emergence of a stable motivational readiness to develop further creative activity. The main task of the teacher at this level is to help form the child's evaluative attitude to himself and his creative abilities, to enrich the child's individual experience in the process of playing and other types of activity with new rules and norms of community living in a team, universal moral values, to support the motivation of an arbitrary responsible choice in the classroom creativity (a responsible attitude to the specified type of activity, and not just as entertainment).

The third level (reflective and creative). The content of the activities of an out-of-school educational institution contains complicated forms of work that require the identification of greater independence, the involvement of cognitive and cognitive processes aimed at supporting verbal thinking and internal speech (when creating products of creative activity, - drawing, application, design, - verbal accompaniment is advisable), the emergence of creative forms of imagination (dreams, fantasizing), awareness of the social significance of the products of one's own creativity, experimentation with various types of forms and activities that are able to reveal the previously hidden creative abilities of the personality of the older preschooler. The main task of the teacher at this level is to take a partner position of co-creation with respect to the personality of an older preschooler as a subject of the creative process; helping the child in mastering the ability to manage himself, regulate his own intentions, actions, etc.

The applied block of the content of out-of-school education presupposes the formation of the following skills in older preschoolers: cognitively motivational: the desire to learn as much as possible new, without experiencing psycho-emotional fatigue, but, on the contrary, receiving only positive emotions from the process of creative activity; intellectual and creative: mastering the necessary knowledge of the chosen profile of the activity of an out-of-school educational institution (scientific, musical, artistic, etc.); organizational and operational: the ability to independently make decisions and have a responsible attitude for their actions and deeds in creatively modeled educational situations (choice of color, combination of the tempo and timbre of the voice, experimenting with technical devices, etc.), mastering the skills of organizing and self-organizing creative activity, managing your feelings and psycho-emotional states; socially communicative: the ability to express their desires and feelings, to interact both with peers in a social environment and with mentors, the ability to work together, co-create, form special personality traits and qualities that are inherent in a creatively directed personality; search-projective: the ability to reveal hidden 
abilities, talents, opportunities, to combine existing creative abilities in various types of creative activity. The indicators of mastering the content of out-of-school education by senior preschoolers are as follows: a high level of creative and cognitive activity; motivational readiness for creative activity; creative direction of the imagination. The content of out-of-school education is aimed at the all-round development of the personality, the formation of a new social experience based on the child's own desires, taking into account his inclinations and inclinations. The methodology of the out-of-school pedagogical process is based on the nature-appropriate creative behavior of the child's personality.

Traditionally, the younger generation's free time, on which out-of-school education is oriented, was calculated based on the fact that a significant part of children's life takes place at school. Accordingly, the free time of the younger student was assessed at 8:00, the middle one - at 6:00, the senior - at 4:00 a day. However, today, with the spread of distance and home education, the sphere of additional education is expanding radically, since the free time of the younger generation is growing 1.5-2 times.

Accordingly, there should be a new strategy for managing out-of-school education, which will allow it to provide a constructive filling of the free time of the younger generation and avoid a whole range of threats that arise in connection with its immersion in the modern media-cultural space. In the process of informatization and digitalization of the educational process, out-of-school education is increasingly taking the leading positions as an environment and a mechanism of social impact on the individual.

The development of its network (quantitative aspect) and diversified activities in accordance with the needs of children and adolescents (qualitative aspect) determines the creation of conditions for self-realization and development of the younger generation in the specific social space of cities and villages. Such a task should be one of the main ones for local self-government, which, in close connection with government bodies and the public, must ensure the preservation and development of the local network of out-of-school education. The main problem here is the lack of understanding of the importance of out-of-school education both by the management bodies and the pedagogical community. Financing of out-of-school education is the competence of local budgets, very often it is carried out on a leftover basis. For local councils, which are communal owners of out-of-school institutions, the goals of out-of-school education management are not always determined by the needs of local communities. Therefore, even a survey analysis of the state of out-of-school education in the country, regions and localities shows the absence of positive shifts in conditions when the importance of the industry is radically increasing. In most cases, local governments consider it an achievement simply to have not drastically reduced the network of outof-school institutions. Meanwhile, in the conditions of a sharp expansion of the boundaries of the free time of children and young people, the task is to adequately expand the network in quantitative and qualitative terms. Extracurricular institutions should become one of the main components of an intellectually rich educational environment, and it is at the municipal level that the management system should ensure the introduction of educational innovations into the practice of extracurricular or extracurricular and effective mechanisms for managing innovative processes.

In our opinion, effective management of out-of-school education at the municipal level is possible only within the framework of the education system, in unity with its other components, as well as cultural, scientific, and health care institutions, in cooperation with regional authorities and the public. Such cooperation requires a new functional imperative of local government, in which the coordination function becomes the main one. The latter presupposes the advancement of the organization of interaction on the basis of the development of an innovative strategy, the introduction of monitoring, support of civil initiatives, and the like. It is the organization of coordination activities at the municipal level that determines the effectiveness of the implementation of innovative processes in out-of-school education and the growth of its 
importance in the educational system. At the present stage of development, the problem of the activities of local education authorities and the system of out-of-school education as subjects of market relations and producers of educational services is also relevant. In our opinion, in modern conditions for the municipal management of out-of-school education, the most effective approach is within the framework of the theory of strategic management. This is a reflection of the general tendencies towards the strategization of regional and municipal governance in the context of decentralization. Strategic management makes it possible, within the powers of local selfgovernment bodies, to explore the characteristics of the educational environment and constantly correlate their own needs and capabilities with the changing needs, potentials and resources of the environment itself. The strategically oriented municipal management of out-of-school education is based on strategic thinking and the use of a strategic planning system, allows the development and use of an integrated system of strategic plans and subordinates current management activities to it. At the same time, the risks of uncertainty in the process of reforming out-of-school education are minimized, the factors of necessary changes are taken into account as much as possible, the information base is formed for making managerial decisions, the level of controllability of the system of additional education is growing, the latter acquires flexibility and dynamism, the prospects for creating systemic interactions in the educational space, all management activities the local authority for the management of out-of-school education acquires the character of a system of actions for the implementation of the development strategy. To determine the strategy, it is necessary to study the state of the out-of-school education system and the factors of its development on the basis of understanding the needs of children and their parents, which will contribute to the achievement of the intended goals and results of activity. The out-of-school education strategy at the municipal level includes a system of targeted actions to optimize its own functioning and substantiation of promising development paths with the possibility of modeling and adjusting in the face of risks. To develop a strategy, it is advisable to use a systematic approach and simulation modeling, which make it possible to choose the most promising direction for the development of the out-of-school education system and the optimal technology for managing it. For the municipal government itself, it is important to understand its own functional imperative, to define its own tasks in the field of out-of-school education, to provide information for management activities, and to create an effective management structure for out-of-school education within the municipality.

\section{CONCLUSION}

Today, on the positive side, it should be noted that the integration of extracurricular institutions with educational institutions of a new type is developing: lyceums, gymnasiums, specialized schools, training and production plants. There are positive changes in the interaction of out-of-school institutions with public and children's and youth organizations, creative unions and the family.

We consider it necessary to note that changing external conditions necessitate the orientation of out-of-school education institutions to improve the effective educational process and those means of activity of the processes that provide it. At the same time, two options for selfdirected development are possible: when the main goal of the institution of out-of-school education becomes adaptive extensive development without significant changes in the basic parameters of functioning, or when the tactical goal is to change the parameters of functioning and launch mechanisms for self-directed development. In the case of adaptive extensive self-governing development, quantitative changes occur, which to some extent violate the stability of the functioning of out-of-school education institutions without changing the principles of the mechanisms. So, striving to "survive" in the conditions of the creation of a market for educational services, many out-of-school education institutions begin to provide additional educational services, 
partly paid. Their introduction is explained by the need for special training of pupils in the demanded branches of knowledge, expanding the cultural horizons of pupils, etc. At the same time, the content of traditional educational areas practically does not change, it does not focus on the relationship between man, society and technology, which, in fact, constitutes the humanitarian and cultural context of the content of out-of-school education. An extensively independently developing institution of out-of-school education is aimed at ensuring a stable state of functioning in the conditions of COVID-19.

We see prospects for further research in the experimental verification of the blocks of the structural and functional model of the content of the activity of an out-of-school educational institution.

Authors' Contributions: Fursykova, T.: conception and design, acquisition of data, analysis and interpretation of data, drafting the article, critical review of important intellectual content; Akimkin, O.: conception and design, acquisition of data, analysis and interpretation of data, drafting the article, critical review of important intellectual content; Hodii, L.: conception and design, acquisition of data, analysis and interpretation of data, drafting the article, critical review of important intellectual content. All authors have read and approved the final version of the manuscript.

Ethics Approval: Not applicable.

Acknowledgments: Not applicable.

\section{REFERENCES}

Carmignolli, A. O. L., Muzzeti, L. R., \& Oliveira, M. F. C. de. (2020). The school's function and the influence of cultural capital on students' performance. Revista Tempos E Espaços Em Educação, 13(32), 1-17.

https://doi.org/10.20952/revtee.v13i32.14392

Castañeda, L., Dabbagh, N., \& Torres-Kompen, R. (2017). Personal learning environments: research-based practices, frameworks and challenges. Journal of New Approaches in Educational Research, 6(1), 1-2.

Galizina, E.G., Palanchuk, N.V., Afonin, M.V., Krivova, A.L., Lyapunova, N.V. (2020). Organization of distance learning for humanities students using google classroom. Revista Inclusiones, 7(Sp), 526-539.

González-Martínez, J.A., Bote-Lorenzo, M.L., Gómez-Sánchez, E., Cano-Parra, R. (2015). Cloud Computing and Education: A State-of-the-Art Survey. Computers and Education, 80, 132-151.

Lacerda, R. P. de, \& Marques, R. N. (2021). My school is my nation project: paths for the construction of school identity. Revista Tempos E Espaços Em Educação, 14(33), e16475. https://doi.org/10.20952/revtee.v14i33.16475

Palshkova, I. O., Balakirieva, V. A., Skoromna, M. V., \& Shpaliarenko, Y. A. (2021). Analysis of the problem on preparing future primary school teachers for the organization of pupils' labor training. Revista Tempos E Espaços Em Educação, 14(33), e16091. https://doi.org/10.20952/revtee.v14i33.16091

Pardeshia, V.H. (2014). Cloud Computing for Higher Education Institutes: Architecture, Strategy and Recommendations for Effective Adaptation. Procedia Economics and Finance, 11, 589-599 https://doi.org/10.1016/S2212-5671(14)00224-X

Parente, C. da M. D. (2020). Multiple-shift schooling: international context and the brazilian case. Revista Tempos $E$ Espaços Em Educação, 13(32), 1-20. https://doi.org/10.20952/revtee.v13i32.12962

Pechenkina, E. (2017). Developing a typology of mobile apps in higher education: A national case-study. Australasian Journal of Educational Technology, 33(4), 134-146 https://doi.org/10.14742/ajet.3228

Santos, I. T. R., Barreto, D. A. B., \& Soares, C. V. C. O. (2020). Formative assessment in the classroom: the dialogue between teachers and students. Journal of Research and Knowledge Spreading, 1(1), 1-14.

Zdanevych, L. V., Kharkivska, A. A., Popovych, O. M., Bobyrieva, O. S., \& Kovrei, D. Y. (2020). Reflection of the personality-oriented approach by the subjects of its implementation in Eastern Europe. Revista Tempos E Espaços Em Educação, 13(32), 1-20. https://doi.org/10.20952/revtee.v13i32.14967

Zlatea, S., \& Cucui, G. (2016). Motivation and performance in higher education. Procedia -Social and Behavioral Sciences, 180, 468-476. 
Received: 31 September 2021 | Accepted: 14 December 2021 | Published: 18 January 2022

(c) (1)

This is an Open Access article distributed under the terms of the Creative Commons Attribution License, which permits unrestricted use, distribution, and reproduction in any medium, provided the original work is properly cited. 